Raynor, E. J., C. E. Whalen, M. Bomberger Brown, and L. A. Powell. 2017. Location matters: evaluating Greater Prairie-Chicken (Tympanuchus cupido) boom chorus propagation. Avian Conservation and Ecology 12(2):17. https://doi.org/10.5751/ACE-01126-120217

Copyright (C) 2017 by the author(s). Published here under license by the Resilience Alliance.

Research Paper

\title{
Location matters: evaluating Greater Prairie-Chicken (Tympanuchus cupido) boom chorus propagation
}

\author{
Edward J. Raynor ${ }^{1}$, Cara E. Whalen ${ }^{1}$, Mary Bomberger Brown ${ }^{1}$ and Larkin A. Powell ${ }^{1}$ \\ ${ }^{1}$ School of Natural Resources, University of Nebraska-Lincoln, USA
}

\begin{abstract}
Anthropogenic disturbances can affect species of conservation concern by influencing their behavior. Of special concern is the possibility that noise from anthropogenic structures in grassland habitats, such as wind turbines and roads, may affect the propagation of the low-frequency boom chorus of lekking male Greater Prairie-Chickens (Tympanuchus cupido). We used sound pressure levels from acoustic recordings taken at 10 leks in the Nebraska Sandhills, USA during 2013 and 2014 in a SPreAD-GIS sound propagation model to make spatial projections of the boom chorus under a variety of conditions including landscape composition, conspecific attendance, and weather. We then used sets of linear mixed models in a model selection process to determine how background noise, female and male lek attendance, time of day, relative humidity, air temperature, and wind speed affected the area of chorus propagation. The predicted area of propagation decreased with increasing background noise $(\beta=-0.09, \mathrm{SE}=0.04)$ and increased with greater female lek attendance $(\beta=0.09, \mathrm{SE}=0.03)$, higher levels of relatively humidity $(\beta=0.07, \mathrm{SE}=0.03)$, and higher air temperatures $(\beta=0.05, \mathrm{SE}=0.03)$. Our analyses provide new insight on how acoustic, social, and meteorological factors influence an important reproductive behavior in an imperiled prairie grouse.
\end{abstract}

\section{L'emplacement importe : évaluation de la propagation des vocalisations réalisées en choeur chez le Tétras des prairies (Tympanuchus cupido)}

RÉSUMÉ. Les perturbations d'origine anthropique peuvent influer sur le comportement d'espèces préoccupantes. Dans les milieux de prairie, l'hypothèse selon laquelle le bruit en provenance de structures anthropiques, comme les éoliennes ou les routes, pourrait affecter la propagation des vocalisations à basse fréquence des mâles Tétras des prairies (Tympanuchus cupido) réalisées en choeur dans les leks est particulièrement préoccupante. Nous avons utilisé le niveau de pression acoustique provenant d'enregistrements effectués à 10 leks dans la région des Sandhills du Nebraska, É.-U., en 2013 et 2014, dans un modèle de propagation de sons SPreAD-GIS, afin de faire des projections spatiales des vocalisations selon une variété de conditions, dont la composition du paysage, la présence de conspécifiques et les conditions météorologiques. Nous avons ensuite évalué un ensemble de modèles linéaires mixtes dans un processus de sélection de modèles afin de déterminer si le bruit de fond, la présence de femelles et de mâles dans les leks, le moment du jour, l'humidité relative, la température de l'air et la vitesse du vent avaient un effet sur l'aire de propagation des vocalisations des mâles réalisées en choeur. L'aire de propagation prédite a diminué avec l'augmentation du bruit de fond $(\beta=-0,09$, erreur-type $=0,04)$, et augmenté avec une plus grande présence de femelles au lek $(\beta=0,09$, erreur-type $=0,03)$, des degrés d'humidité relative plus élevés ( $\beta$ $=0,07$, erreur-type $=0,03)$ et des températures de l'air plus élevées $(\beta=0,05$, erreur-type $=0,03)$. Nos analyses révèlent de nouvelles perspectives sur les effets de facteurs sonores, sociaux et météorologiques sur un important comportement de reproduction chez une espèce de tétras en danger.

Key Words: anthropogenic noise; Greater Prairie-Chicken; lek-mating grouse; Sandhills; sound propagation; Tympanuchus cupido; wind energy

\section{INTRODUCTION}

Anthropogenic disturbances can affect species of conservation concern by influencing their reproductive behavior. One of the leading causes of conservation concern for acoustically sensitive organisms is low-frequency noise caused by roads and energy development (Barber et al. 2010, Blickley and Patricelli 2010, 2012, Francis and Barber 2013). More than $80 \%$ of the land in the continental United States is within $\sim 1 \mathrm{~km}$ of a road (Riitters and Wickham 2003), and energy development is predicted to increase substantially in coming decades (Fargione et al. 2012). Some of the most comprehensive studies on the effects of anthropogenic noise on wildlife have focused on impacts of noise from roads and natural gas extraction activities. In these studies, exposure to road noise resulted in reduced body condition of songbirds (Ware et al. 2015, McClure et al. 2017) and noise from gas extraction infrastructure impaired hunting success of Northern Saw-whet Owls (Aegolius acadicus; Mason et al. 2016) and reduced pairing success of Ovenbirds (Seiurus aurocapilla; Habib et al. 2007, Bayne et al. 2008). Given the ubiquity of human-created noise across landscapes, e.g., $~ 88 \%$ of the continental USA experiences noise levels elevated because of human activities (Mennitt et al. 2013), it is important for conservation efforts to evaluate the impact of the acoustic environment on avian behavior. 
The effects of noise caused by roads, turbines, and ancillary structures at wind energy facilities on the reproductive behavior of birds remain mostly unexplored (Smith and Dwyer 2016, Gibson et al. 2017). For species that use acoustic signals, e.g., song, the masking effects of wind facility noise could have fitness consequences by interfering with their communication and altering their intraspecific interactions, including mate choice (Riebel 2009, Barber et al. 2011, Shannon et al. 2016). This addition to the acoustic environment is a potential concern for species that produce vocalizations at acoustic frequencies similar to that of the noise (Lohr et al. 2003, Kight et al. 2012, Zwart et al. 2016, Raynor et al. 2017). If individuals cannot hear conspecific vocalizations against the background noise, they may lose opportunities to find mates and reproduce (Lohr et al. 2003). Because anthropogenic noise is dominated by low-frequency energy that diminishes in intensity toward higher frequencies (Francis 2015), birds that produce low-frequency vocalizations may be impacted more than species that communicate using highfrequency vocalizations.

In addition to sound levels of vocalizations and inherent landscape background noise, environmental factors such as local climate and topographic conditions impact the transmission of sound. In the absence of interference, sound propagates geometrically outward, and sound levels decline as the square of the distance from the source (spherical spreading loss). As it travels across the landscape, acoustic energy is absorbed by the atmosphere as a function of elevation, air temperature, and humidity (Sutherland et al. 1974). Moreover, air temperature and wind gradients cause sound waves to refract, altering the spatial pattern of propagation and determining where a sound will be most audible to listeners (Ingård 1953). Acoustic energy can be absorbed by the ground (Aylor 1972) and dissipated by vegetation (Fang and Ling 2003). Landscape structure and terrain determine the relative importance of ground versus atmospheric effects on acoustic energy; sound may propagate long distances from hilltops or across valleys when not obstructed by a terrain barrier such as an elevated road, steep hill, or ridgeline (Piercy et al. 1977, Embleton 1996). Therefore, the degree to which audible sound reaches listeners depends on underlying environmental conditions.

The Greater Prairie-Chicken (Tympanuchus cupido pinnatus) is a species of conservation concern that occupies grasslands in the Great Plains of North America. These habitats are threatened by land-use change, e.g., modification for agricultural purposes and urbanization, including increased energy development in the form of wind turbine facilities and their associated roads and ancillary structures (Fargione et al. 2012, Hovick et al. 2014). Although much attention has focused on habitat use in relation to habitat loss due to energy development (Pruett et al. 2009, McNew et al. 2014, Winder et al. 2014), no studies have quantified landscapescale acoustic propagation by lekking prairie-chickens. In particular, the propagation of male prairie-chicken's primary advertising vocalization (Robel 1966, Sparling 1981a, Riede et al. 2016), the boom, or boom chorus when multiple males are vocalizing simultaneously (Höglund and Alatalo 2014, RehbergBesler et al. 2017), has not been investigated. Understanding this phenomenon could aid in the management of Greater PrairieChickens and other lekking grassland birds (Blickley and Patricelli 2010, Blumstein et al. 2011). For example, the audibility of leks may be influenced by increasing anthropogenic disturbance, which managers can take into account when siting anthropogenic structures near known leks or implementing noisecontrol measures.

We used a sound propagation model and recordings of vocalizations of male Greater Prairie-Chickens on leks located along a gradient of high to low background noise levels to identify factors influencing the spatial extent of boom chorus propagation in a relatively unfragmented grassland ecosystem, the Nebraska Sandhills (Fig. 1 inset; Bleed and Flowerday 1998). We tested the following three hypotheses. (1) Because background noise can be elevated near roads and wind turbines, which are adjoining features at wind energy facilities (Pruett et al. 2009), we expected increased background noise would negatively affect boom chorus propagation from leks exposed to high background noise. An increase in background noise would decrease the spatial extent of the chorus that is audible on the landscape because noise that overlaps the frequency of vocalizations can reduce the area on a landscape where vocalizations are audible (Barber et al. 2010, Francis and Barber 2013). (2) Given that sound transmission is poor in open grasslands because of meteorological factors such as thermal turbulence and high winds (Morton 1975, Marten and Marler 1977), we predicted that boom chorus propagation from leks will not be spatially uniform across the landscape and that meteorological factors modulate variability in chorus propagation. If wind speed reduces sound propagation and airmoistening factors promote propagation, then the spatial extent of boom chorus would have an inverse relationship with wind speed and air-moistening variables like relative humidity and air temperature. (3) Finally, given that male display efforts increase with lek size (Höglund and Alatalo 2014), we predicted greater spatial extent of chorus propagation with increasing lek attendance by male and female prairie-chickens.

Fig. 1. Location of the study area near Ainsworth, Brown County, Nebraska, USA $\left(42.455^{\circ} \mathrm{N}, 99.915^{\circ} \mathrm{W}\right)$, on the northeastern edge of the Nebraska Sandhills ecoregion (inset; study site in gray square). Approximate locations of Greater Prairie-Chicken (Tympanuchus cupido) leks used for recordings in this study are marked by blue circles.

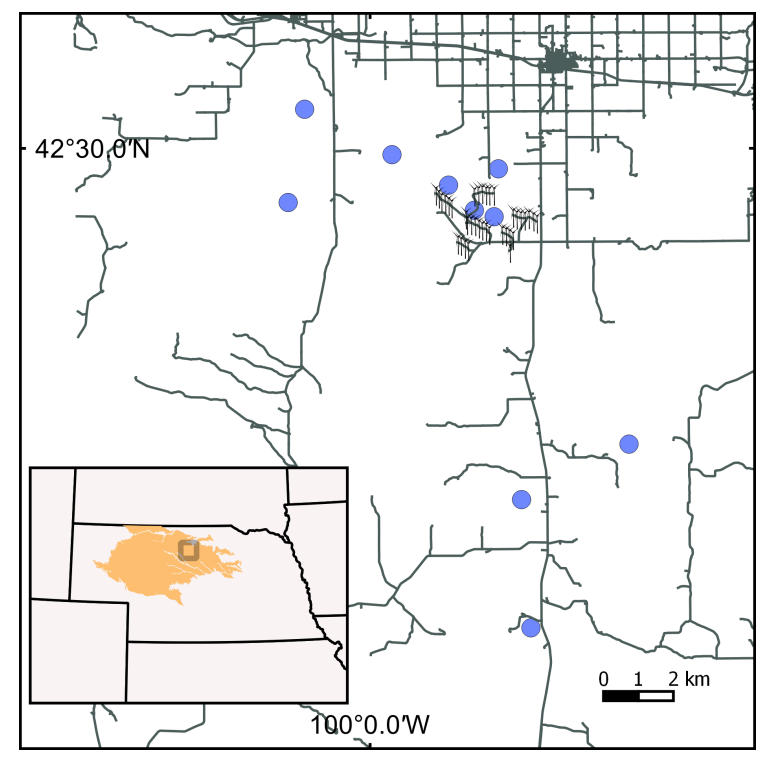




\section{METHODS}

\section{Study species}

Greater Prairie-Chickens occupy open grasslands of the Great Plains and Midwest of North America and employ a lek-mating social-system. Males display in groups at lek sites, which the females visit for the sole purpose of mating (Nooker and Sandercock 2008). An important component of the lek display is a low-frequency "boom" vocalization produced by males. Because of its low-frequency $(\sim 0.300 \mathrm{kHz} ; 2-8 \mathrm{kHz}$ for most passerines), the boom has the potential to travel long distances (e.g., $>3 \mathrm{~km}$ ) and serves to advertise the presence of the lek or convey mate quality information (Hamerstrom et al. 1957, Hamerstrom and Hamerstrom 1960, Sparling 1981a,b, 1983).

\section{Study area}

Our study area was centered on a pre-existing wind energy facility owned and operated by the Nebraska Public Power District located approximately $10 \mathrm{~km}$ south of Ainsworth, Brown County, Nebraska, USA $\left(42.455^{\circ} \mathrm{N}, 99.915^{\circ} \mathrm{W}\right.$, mean \pm SD: $801 \pm 7 \mathrm{~m}$ above sea level; Fig. 1). The facility, built in 2005, consists of 36 wind turbines that occupy $15.3 \mathrm{~km}^{2}$, including associated infrastructure (Nebraska Public Power District (NPPD 2017); URL: http://nppd.com/about-us/power-plants-facilities/windgeneration/ainsworth-facts-and-figures/). All the turbines are constant rotation units, therefore blade rotation speed remains constant as will turbine-induced sound pressure levels, irrespective of wind speed. Annual average daily traffic for highway NE-7, which traverses the study area, is 502 vehicles per day (2013: 506, 2014: 527). Cars and motorcycles make up 50\% of use with heavy trucks (17\%), and other two-axle vehicles (33\%) taking the remainder (Nebraska.gov: http://dot.nebraska.gov/ media/3811/annual-traffic-count-data.pdf ). Road density of the $44 \mathrm{~km}^{2}$ study area is $0.49 \mathrm{~km} / \mathrm{km}^{2}$. Additional details on study area vegetation and climate are provided in Appendix 1.

A 24-km long acoustic sampling gradient was established to record chorusing male prairie-chickens on leks ranging from anthropogenically disturbed (roads and wind turbines) to natural conditions (grasslands). Along the gradient, three leks were within $950 \mathrm{~m}$ (range: $703-950 \mathrm{~m}$ ) of wind turbines and within $908 \mathrm{~m}$ of roads (range: 76-908 m), and two leks were within $619 \mathrm{~m}$ of a road only (range: 580-619 m; Figs. 1 and 2). Five leks were at least $1065 \mathrm{~m}$ distant from any anthropogenic noise sources (range: 3614-15365 $\mathrm{m}$ for wind turbines and range: 1365-2664 $\mathrm{m}$ for roads; Figs. 1 and 2).

\section{Acoustic measurements}

In 2013 and 2014, we recorded boom chorus sounds at a lek for one morning then moved the audio recorders to a different lek a subsequent morning for recording; recordings were made under conditions with little to no wind $(<18 \mathrm{~m} / \mathrm{s})$ and no precipitation. We systematically rotated through the leks, recording at each lek once every two weeks. We recorded at each lek six mornings during the lekking season, but in some cases, we recorded more if a previous recording session had audio recorder malfunctions. The exact timing of recording depended on the daily activity of the attending prairie-chickens, which became earlier in the morning with earlier sunrise times during the study season, but was generally for three hours between 05:00 and 10:00 CST. Recordings were made by placing 10 SM2+ audio recorders with omnidirectional microphones (Wildlife Acoustics, Maynard MA, USA) at different distances from leks; microphones were placed $0.25 \mathrm{~m}$ above the ground, the height of a prairie-chicken's head (see Whalen 2015, Whalen et al. 2017, Whalen et al. 2018 for details). Microphones were placed on two sides of the lek, $50 \mathrm{~m}$ from the lek edge. For every recording session, the arrival of the first and the departure of the last prairie-chicken was noted while observing from a blind at the edge of the lek. The number of males and females attending the lek were recorded every 20 minutes during each recording session (Smith et al. 2016). We measured weather conditions during sound recordings by placing a Kestrel 4500 Weather Meter (Nielsen-Kellerman, Chester, PA) near the lek to automatically record wind speed, wind direction, air temperature, and relative humidity data every five minutes (Table 1). We positioned the weather meter such that it was 0.25 $\mathrm{m}$ above the ground to match the height of the microphones and prairie-chicken heads. We calibrated our recorders by playing a signal with a known sound pressure level (SPL) at a specific frequency and using this to adjust values to the correct levels (details in Whalen 2015 and Whalen et al. 2018). Calibrated sound levels are necessary for acoustic studies for meaningful comparisons over time and different locations (McKenna et al. 2016). See Appendix 1 for descriptions of the methodology used to calibrate acoustic recording equipment and to monitor weather conditions.

Fig. 2. Background noise at $\sim 0.300 \mathrm{kHz}$ from 10 Greater Prairie-Chicken (Tympanuchus cupido) leks with different proximities to roads near Ainsworth, Nebraska, USA and used as lek-specific background noise input in the sound propagation model. Each column of points represent lekspecific background noise values recorded during boom chorus events. Leks are plotted in ascending order of distance from road with lek 1 being $76 \mathrm{~m}$ from a road and lek 10 being $2664 \mathrm{~m}$ from a road. Leks 1, 4, and 5 were located closest to the wind energy facility.

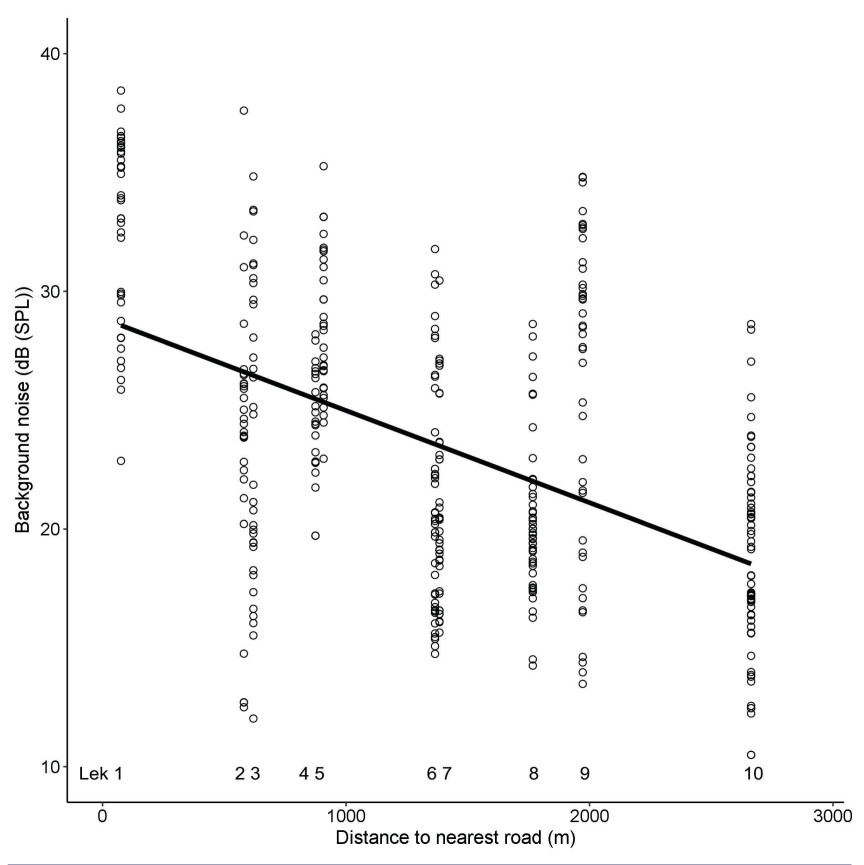


Table 1. Summary of monthly at-lek weather conditions and lek attendance for Greater Prairie-Chicken (Tympanuchus cupido) during male chorus recordings of leks near Ainsworth, Brown County, Nebraska, USA, 2013-2014. Number of recording days for each month is indicated next to month.

\begin{tabular}{|c|c|c|c|c|c|c|c|c|c|}
\hline \multirow[b]{2}{*}{ Month } & \multicolumn{3}{|c|}{ Temperature $\left({ }^{\circ} \mathrm{C}\right)$} & \multicolumn{3}{|c|}{ Humidity (RH) } & \multicolumn{3}{|c|}{ Wind speed $(\mathrm{m} / \mathrm{s})$} \\
\hline & Mean & $\mathrm{SD}$ & Range & Mean & $\mathrm{SD}$ & Range & Mean & $\mathrm{SD}$ & Range \\
\hline $\operatorname{March}(n=6)$ & -0.98 & 5.42 & $-10.25-8.50$ & 76.61 & 15.12 & $49.75-100.00$ & 3.86 & 2.59 & $0-8.35$ \\
\hline April $(\mathrm{n}=20)$ & 2.69 & 5.49 & $-9.40-14.83$ & 78.43 & 13.31 & $35.45-100.00$ & 5.98 & 4.14 & $0-18.48$ \\
\hline May $(\mathrm{n}=35)$ & 8.11 & 6.18 & $-5.43-20.72$ & 85.23 & 14.02 & $40.33-100.00$ & 5.03 & 3.79 & $0-14.58$ \\
\hline \multirow[t]{3}{*}{ June $(\mathrm{n}=5)$} & 11.40 & 3.35 & $6.28-18.55$ & 91.40 & 5.66 & $78.20-98.28$ & 3.69 & 2.41 & $0-8.83$ \\
\hline & \multicolumn{3}{|c|}{ Wind direction $\left(^{\circ}\right)$} & \multicolumn{3}{|c|}{ Males } & \multicolumn{3}{|c|}{ Females } \\
\hline & Mean & $\mathrm{SD}$ & Range & Mean & $\mathrm{SD}$ & Range & Mean & $\mathrm{SD}$ & Range \\
\hline $\operatorname{March}(n=6)$ & 210.06 & 70.61 & $80.00-312.50$ & 7.08 & 3.17 & $1-14$ & 0.05 & 0.23 & $0-1$ \\
\hline April $(n=20)$ & 218.76 & 73.20 & $57.50-345.50$ & 9.34 & 3.36 & $1-16$ & 0.46 & 1.03 & $0-6$ \\
\hline May $(n=35)$ & 198.09 & 84.78 & $2.33-345.17$ & 7.35 & 3.77 & $1-18$ & 0.21 & 0.61 & $0-4$ \\
\hline June $(\mathrm{n}=5)$ & 234.76 & 57.30 & $103.00-301.83$ & 6.37 & 2.08 & $2-9$ & 0.00 & 0.00 & 0 \\
\hline
\end{tabular}

\section{Boom chorus and background noise measurements}

We used Raven Pro 1.4 acoustic analysis software (Hann window type, $100 \mathrm{~ms}$ window size, $14.4 \mathrm{~Hz} 3 \mathrm{~dB}$ filter bandwidth; Bioacoustics Research Program 2014) to create the spectrograms used in our sound file analyses. We created selections from our recordings and averaged sound data over five-minute periods that coincided with when lek attendance data were recorded. Fiveminute selections with waveform distortion, i.e., clipping, for more than 30 seconds, which make sound recordings unusable for acoustic analysis (Howard and Murphy 2007), were regarded as low-quality recordings and not used in our analyses.

We located the peak created by the boom chorus on the spectrograms and measured the frequency and sound pressure levels of the chorus peak (Fig. A1.1). We averaged the boom chorus sound pressure level values derived from the recording points $50 \mathrm{~m}$ on each side of the lek for use as the "source" sound level for sound-mapping of boom chorus (Table A1.1). We measured background noise at the two bases of the chorus peak by measuring the frequency and sound pressure level at the point where the chorus peak began to rise up from the background noise, as well as at the point where the chorus peak faded back into the background noise; these paired values were averaged to represent background noise levels (Fig. A1.1). Next, we averaged noise values recorded at the two points $50 \mathrm{~m}$ from the lek, and these values were used in sound propagation models as representative background noise levels for grassland cover for each recording event (Table A1.2; described in chorus propagation section below).

\section{Chorus propagation}

To account for the influences of spherical spreading loss, atmospheric absorption, wind, vegetation, terrain profiles, and ground characteristics on sound propagation (Ingård 1953, Aylor 1972, Fang and Ling 2003), we used SPreAD-GIS v.4.2 (Reed et al. 2010, 2012) to map chorus propagation from active leks. SPreAD-GIS is based on the System for the Prediction of Acoustic Detectability (SPreAD) (Harrison et al. 1980), and uses the physics of sound propagation to make spatially explicit sound level predictions across a landscape. SPreAD-GIS is available in the open-source Sound Mapping Tools for ArcGIS with the Spatial Analyst extension (Keyel et al. 2017). In addition to sound pressure levels (dB) from a source, SPreAD-GIS also incorporates topography (Digital Elevation Model), weather conditions (Table 1), and background sound pressure level (Table A.1.2) data for different types of landscape cover (Homer et al. 2012) to create spatially explicit maps of source sound above background noise (excess attenuation; Reed et al. 2010, 2012).

In our analyses, source sound (Table A1.1) and background noise values for grassland cover (Table A.1.2) were represented by lek boom chorus and lek background noise values (unweighted decibels [reported as $\mathrm{dB}$ ] re $20 \mu \mathrm{Pa}$ ), respectively. All sound pressure level values were obtained from spectrograms at $\sim 0.300$ $\mathrm{kHz}$, which is the peak frequency of the prairie-chicken chorus at our study site (Whalen et al. 2017). This frequency is within the $0.315 \mathrm{kHz}$ one-third octave frequency band (range: $0.282-0.355$ $\mathrm{kHz}$ ) available in SPreAD-GIS for sound propagation modeling (Reed et al. 2010, 2012, Keyel et al. 2017). Hearing sensitivity data from six female Greater Prairie-Chickens indicated this bandwidth falls within their hearing range (Walsh et al. 2015). For each lek recording event $(n=383$ five-minute boom chorus selections), we used the sound propagation model to predict the area surrounding a lek exposed to the boom chorus in square kilometers $\left(\mathrm{km}^{2}\right)$. This area represents the spatial cover of excess attenuation where the sound from the source (a lek's boom chorus) exceeds background noise (a lek's acoustic environment) and is likely audible (Reed et al. 2010, 2012). Further details on sound propagation modeling with SPreAD-GIS and validation are provided in Appendix 1.

\section{Statistical analyses}

We examined the effects of lek-specific background noise levels (dB), number of male and female prairie-chickens attending a lek, weather conditions, time since midnight, and day of year on the total area $\left(\mathrm{km}^{2}\right)$ of boom chorus propagated from a lek. Underlying background noise levels ( $\mathrm{dB}$ [SPL]), lek proximity to the nearest road $(\mathrm{m})$, conspecific attendance, and weather conditions, e.g., wind speed $(\mathrm{m} / \mathrm{s})$, relative humidity $(\%)$, air temperature $\left({ }^{\circ} \mathrm{C}\right)$, were lek-specific factors with potential to cause 
variation in the predicted area of propagation. Additional factors that could impact variation in propagation area were time-specific characteristics of the lek recordings, i.e., time since midnight and day of the year. Distance to nearest road (m) for each lek was calculated using the Near tool in ArcGIS 10.4.1 (ESRI 2011). We could not separate lek distance to nearest wind turbine and road, and therefore the source of background noise, because a service road was located within $50 \mathrm{~m}$ of each wind turbine. Therefore, we chose to interpret the effect of background noise on boom propagation as a proxy for distance to nearest road because an a priori analysis showed that lek background noise levels increased with decreasing distance to nearest road $\left(\mathrm{t}_{1381}=-11.35, \mathrm{P}<0.001\right.$, $r=0.50$; Fig. 2). We used linear mixed models (LMM) with the lme4 package (Bates et al. 2015) in R ( $R$ Development Core Team 2016) to determine potential drivers of boom chorus propagation. We used an information criterion approach to compare Akaike information criterion corrected for small sample size $\left(\mathrm{AIC}_{\mathrm{c}}\right)$ scores between models. Lek ID was included as a random intercept to account for within-lek correlation and repeated sampling of individual leks. To improve the fit of the model and allow for direct comparison of effect size of each predictor variable, all fixed effects included in the models were converted to $z$ scores using the scale function in R. For all analyses, we created a correlation matrix to test for multicollinearity among covariates and removed covariates to avoid multicollinearity if $r$ $\geq 0.50$. After configuring the full model (chorus area $=$ humidity, wind speed, air temperature, number of males, number of females, recording event background noise, time since midnight + Lek ID [random intercept]), we used an automated model selection process that evaluated subsets of all possible combinations of models. Coefficients from models in the set of models within 2 $\triangle \mathrm{AIC}_{\mathrm{c}}$ of the top model were model-averaged, and conditional averages for effect size were calculated to provide the relative importance of each predictor. We then calculated $85 \%$ and $95 \%$ confidence intervals for each model-averaged predictor included in the set of models within $2 \Delta \mathrm{AIC}_{\mathrm{c}}$ and identified informative predictors as those with $85 \%$ confidence intervals not overlapping zero (Arnold 2010, Ware et al. 2015). Uninformative predictors were interpreted as not affecting boom chorus propagation.

\section{RESULTS}

A total of 220 recording events at 7 leks in 2013 and a total of 163 recording events at 4 leks in 2014 were used for sound propagation modeling. We visited each lek during $5.7 \pm 1.8$ (mean $\pm \mathrm{SD}$ ) and $7.0 \pm 2.9$ mornings spread across the lekking season (March to June) in 2013 and 2014, respectively. We used 3.4 \pm 1.9 chorus recording events each morning for sound propagation modeling at each lek in 2013 and $3.8 \pm 2.1$ in 2014 .

The mean $( \pm \mathrm{SD})$ chorus propagation area across all samples and leks was $0.30(0.54) \mathrm{km}^{2}$, and the median area of boom chorus propagated from a lek was $0.1 \mathrm{~km}^{2}$ (range of lek-specific means: 0.07 to $0.80 \mathrm{~km}^{2}$ ). Propagation tended to be less extensive in the early lekking season period of March-early April (Fig. 3A-C, Table 2) and late lekking season (Fig. 3G-I), while the broadest boom chorus area occurred from late April-early May (Fig. 3DF), a pattern that corresponds to the peak of prairie-chicken lek attendance (Table 1).
Table 2. Monthly mean ( \pm SD) chorus area $(\mathrm{km} 2)$ for Greater Prairie-Chicken (Tympanuchus cupido) leks near Ainsworth, Brown County, Nebraska, USA, 2013-2014.

\begin{tabular}{lccc}
\hline \hline & Mean & SD & Range \\
\hline March & 0.09 & 0.11 & $0.002-0.35$ \\
April & 0.32 & 0.71 & $0.002-4.05$ \\
May & 0.36 & 0.48 & $0.002-2.48$ \\
June & 0.03 & 0.01 & $0.001-0.06$ \\
Total & 0.30 & 0.54 & $0.001-4.05$ \\
\hline
\end{tabular}

\section{Environmental influences of boom chorus propagation area}

We found collinearity between air temperature and day of the year $(r=0.62)$, so we removed the day of the year from our analyses and retained air temperature, because we were most interested in the effects of lek-specific environmental variables on boom chorus propagation. Lek distance to nearest road and background noise were positively correlated $(r=0.50)$, thus, we evaluated the effect of background noise because this environmental variable corresponds with proximity to roads. All models with at least one environmental factor were ranked higher than the null model $\left(\Delta \mathrm{AIC}_{\mathrm{c}}=15.88\right.$, Table 3$)$, indicating that the environmental variables at lek locations provided substantial information regarding propagation of the boom chorus from leks. When considering environmental influences on boom chorus propagation, no single top random-intercept model was supported. Instead, 6 models of 128 had substantial empirical support with $\Delta \mathrm{AIC}_{\mathrm{c}}<2$ (Table 3, model weight, $w_{i}$, range: $0.11-0.28$ ), so we model-averaged coefficients across the six top models.

Table 3. Model selection for environmental variables influencing area of Greater Prairie-Chicken (Tympanuchus cupido) boom chorus $\left(\mathrm{km}^{2}\right)$ surrounding a lek near Ainsworth, Brown County, Nebraska, USA, 2013-2014. Only candidate models within $2 \mathrm{AIC}_{\mathrm{c}}$ (Akaike Information Criterion adjusted for small sample size) of the best model are included and compared to the null model with no fixed effects.

\begin{tabular}{lccc}
\hline \hline K Fixed effects & $\mathrm{AIC}_{c}$ & $\Delta \mathrm{AIC}_{c}$ & $w_{i}$ \\
\hline 8 Noise, Females, Humidity, Temperature, Roads & 642.1 & 0.00 & 0.24 \\
7 Noise, Females, Humidity, Roads & 642.9 & 0.77 & 0.17 \\
7 Noise, Females, Humidity, Temperature & 643.0 & 0.91 & 0.15 \\
6 Noise, Females, Humidity & 643.5 & 1.37 & 0.12 \\
9 Noise, Females, Males, Humidity, Temperature, & 643.6 & 1.44 & 0.12 \\
$\quad$ Roads & & & \\
9 Noise, Females, Humidity, Temperature, Wind & 643.9 & 1.74 & 0.10 \\
$\quad$ speed, Roads & & & \\
9 Noise, Females, Time since midnight, Humidity, & 643.9 & 1.79 & 0.10 \\
$\quad$ Temperature, Roads & 658.9 & 16.79 & 0.00 \\
3 Intercept & & &
\end{tabular}

Background noise, relative humidity, and the number of females attending a lek were included in all of the models with $\Delta \mathrm{AIC}_{\mathrm{c}}<2$ (Table 3), suggesting their importance as predictors for the area of 
Fig. 3. Propagation of male Greater Prairie-Chicken (Tympanuchus cupido) boom chorus predicted at a one-third octave frequency bandwidth of $0.315 \mathrm{kHz}$ over the lekking season (early April [top row], late April [middle row], and late May [bottom row]) from three representative leks: left panel $(A, D, G)$ is a lek $>1365 \mathrm{~m}$ from a road/wind facility, middle panel $(\mathrm{B}, \mathrm{E}, \mathrm{H})$ is a lek within $620 \mathrm{~m}$ of a road, and right panel (C,F,I) is lek within $920 \mathrm{~m}$ of the wind energy facility. Boom chorus propagation is shown with $5 \mathrm{~dB}$ contours (gray lines) around each lek (black dot in center of contour lines) near Ainsworth, Brown County, Nebraska, USA. Black lines indicate area where the predicted boom chorus sound level (dB) has fallen to $5 \mathrm{~dB}$ above ambient background level, and the outermost gray contour line indicates where boom chorus meets background level, $0 \mathrm{~dB}$. White dashed lines are roads.
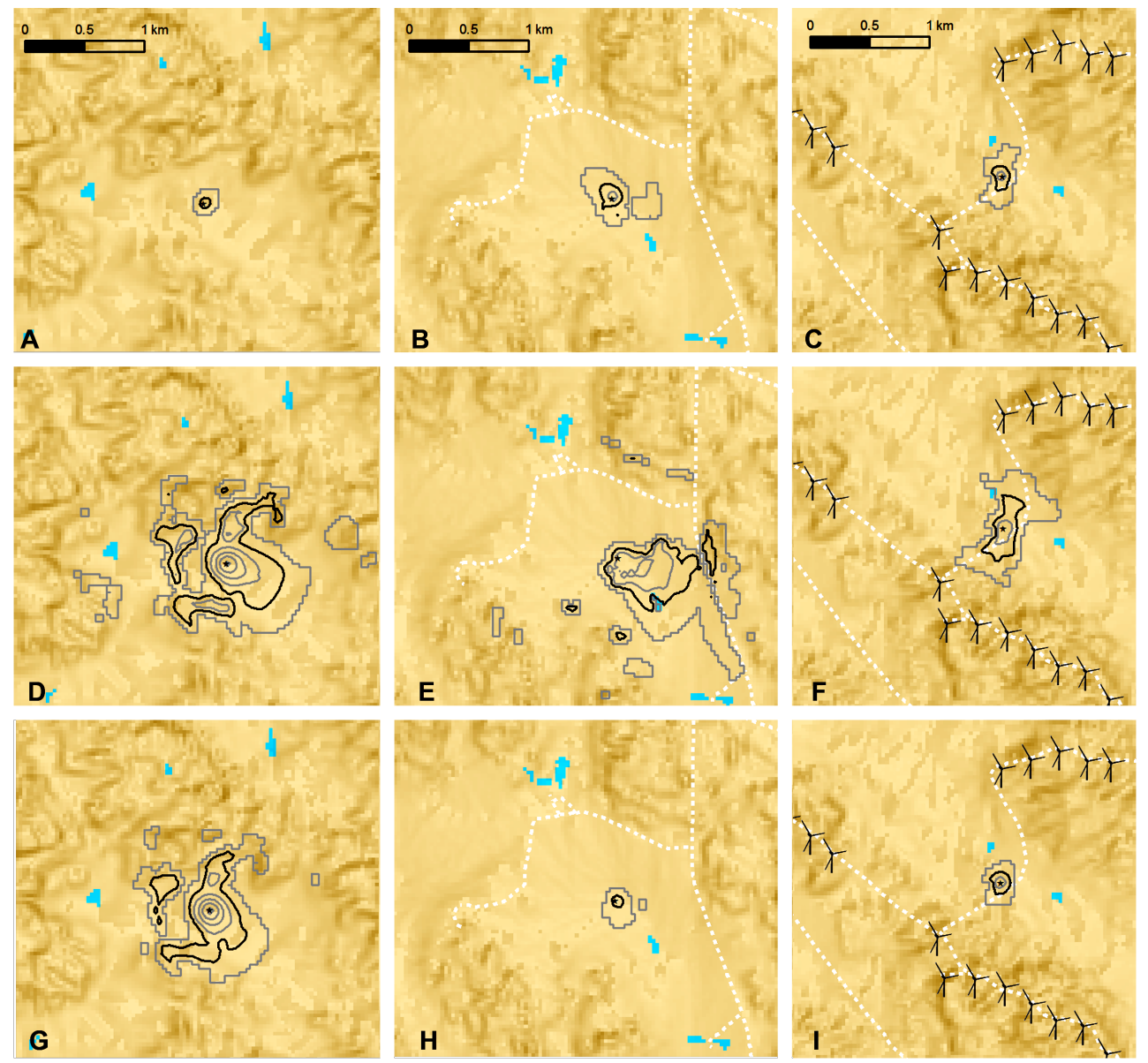

audible boom chorus. The area of audible boom chorus around a lek decreased with increasing background noise (modelaveraged coefficients; $\beta=-0.09, \mathrm{SE}=0.04$ ), whereas boom chorus propagation was positively influenced by relative humidity $(\beta=$ $0.07, \mathrm{SE}=0.03)$ and the number of females attending a lek $(\beta=$ 0.09, $\mathrm{SE}=0.03$; Table 4, Fig. 4). Model-averaged coefficients indicated Greater Prairie-Chicken boom chorus propagation was broader with increasing air temperature $(\beta=0.05, \mathrm{SE}=0.03$; Fig. 4D). We did not find evidence to suggest that the number of males at leks, wind speed, and time since midnight affected the area of chorus propagation (Table 4).

\section{DISCUSSION}

The acoustic environment surrounding leks, the number of females at leks, and the location of leks in relation to the nearest road affect the ability of the audible boom chorus to be propagated across a grassland landscape. The positive effects of air temperatures and relative humidity were expected because of the propagation model's explicit use of those variables in the model functions, which represent actual conditions under which birds vocalize (Harris 1966). To our knowledge, this is the first study to describe the landscape-level propagation of prairiechicken boom chorus away from leks and reveals the importance of a lek's location, conspecific attendance, and weather in the spatial extent to which chorus can be heard.

We determined that the audible area of prairie-chicken boom chorus was predicted to be largest at leks with the least exposure to anthropogenic disturbance because area of chorus decreased with increased background noise. Leks in our study that were near wind turbines had the potential for two impacts on the area of 
Table 4. Influence of fixed effects on Greater Prairie-Chicken (Tympanuchus cupido) boom propagation from leks near Ainsworth, Brown County, Nebraska, USA, 2013-2014. Significant and marginally significant fixed effects, based on $85 \%$ and $95 \%$ confidence intervals, respectively, shown in bold. Estimates $( \pm \mathrm{SE})$ are derived from model-averaging of the set of 6 models $<2 \Delta \mathrm{AIC}_{\mathrm{c}}$ of the top model.

\begin{tabular}{|c|c|c|c|c|c|c|c|}
\hline \multirow[t]{2}{*}{ Variable } & \multirow[t]{2}{*}{ Estimate } & \multirow{2}{*}{$\begin{array}{c}\text { SE } \\
\text { (Estimate) }\end{array}$} & \multicolumn{2}{|c|}{$85 \%$ C.I. } & \multicolumn{2}{|c|}{$95 \%$ C.I. } & \multirow{2}{*}{$\begin{array}{c}\text { Relative } \\
\text { importance }\end{array}$} \\
\hline & & & Lower & Upper & Lower & Upper & \\
\hline Intercept & 0.36 & 0.07 & 0.24 & 0.44 & 0.20 & 0.48 & - \\
\hline Background noise & -0.09 & 0.04 & -0.15 & -0.04 & -0.16 & -0.02 & 1 \\
\hline Females & 0.09 & 0.03 & 0.05 & 0.13 & 0.03 & 0.15 & 1 \\
\hline Humidity & 0.07 & 0.03 & 0.03 & 0.11 & 0.01 & 0.13 & 1 \\
\hline Temperature & 0.05 & 0.03 & 0.01 & 0.09 & -0.01 & 0.11 & 0.66 \\
\hline Males & -0.03 & 0.04 & -0.09 & 0.02 & -0.10 & 0.04 & 0.27 \\
\hline Time & -0.01 & 0.03 & -0.06 & 0.03 & -0.07 & 0.04 & 0.11 \\
\hline Wind speed & -0.02 & 0.03 & -0.06 & 0.03 & -0.08 & 0.04 & 0.12 \\
\hline
\end{tabular}

Fig. 4. Predicted relationship and associated $95 \%$ confidence intervals for Greater Prairie-Chicken (Tympanuchus cupido) boom chorus propagation area $\left(\mathrm{km}^{2}\right)$ from models used to assess drivers of chorus propagation based on lek-specific environmental conditions near Ainsworth, Nebraska, 2013 and 2014.
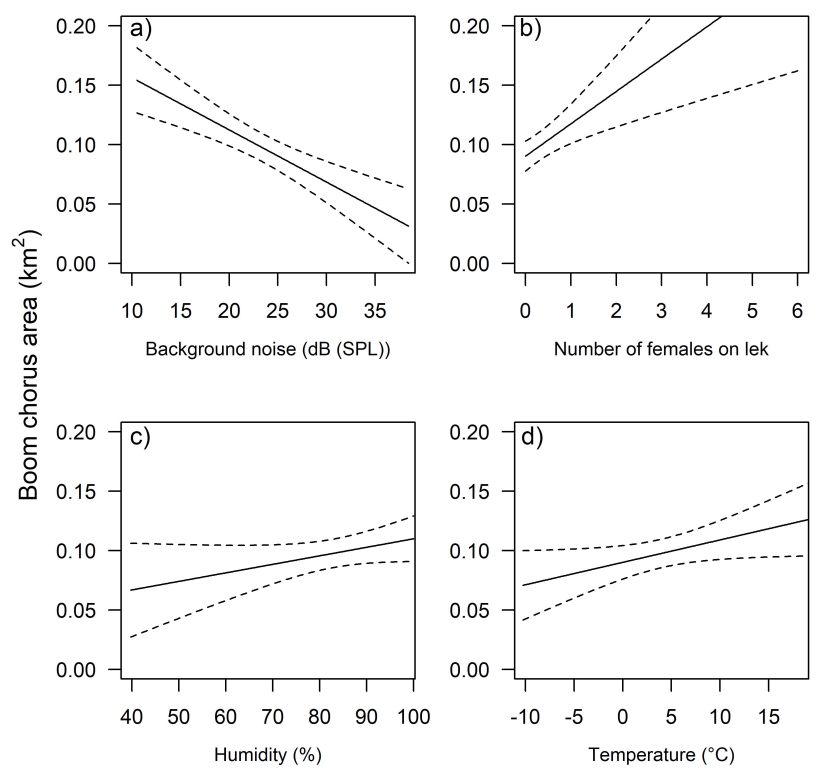

predicted chorus propagation. First, the input sound pressure levels for background noise at the five leks closest to roads (including three that were in the midst of the wind facility) had some of the highest sound pressure levels among our recordings (Fig. 2). Second, leks near wind turbines are also near roads that are built to service the turbines, and the SPreAD-GIS model is structured to decrease the propagation distance of sound as it passes over roads and other elevated features on the landscape. In contrast, leks in open grasslands (far from roads and turbines) experienced less background noise, which resulted in lower input values for background noise.
We collected empirical acoustic data throughout the lekking season, which enabled us to evaluate chorus propagation from early to late spring. This period spans the progression of diurnal humidity and air temperature over the lekking season. Relative humidity and air temperature were expected to affect the chorus propagation, but we posit hen activity at leks was a stronger driver of propagation than these local climate conditions. Our qualitative finding of propagation area being broadest during the middle of the lekking season (Table 2) when attendance peaks (Sparling 1981a) bolsters this hypothesis.

The number of males present on a lek appears to have less of an effect on boom chorus sound levels than the number of females present; males seem to boom (and chorus) more loudly when more females are present, enhancing the propagation of the chorus over the landscape. This result is in agreement with Whalen (2015); the number of males attending a lek had a relatively weak effect on the distance the chorus traveled, the effect of female attendance was stronger. We surmise that the effect of conspecific attendance on chorus area may be due to (1) more aggression between males, and fewer vocalizations when fewer females are present or (2) more females present on the lek increases the synchrony in the males' booming (Rehberg-Besler et al. 2017) and enhancing chorus sound levels.

We posit that a broader area of boom chorus surrounding a prairie-chicken lek will result in a greater probability of females locating and attending a lek. During the breeding season, female Greater Prairie-Chickens occupy the area within several kilometers of a lek (Winder et al. 2014), visit the lek for a short period to copulate with males (Robel 1966), and then depart to initiate nesting (Hamerstrom and Hamerstrom 1949, Hamerstrom et al. 1957, Nooker and Sandercock 2008). Females likely use the boom chorus to aid in spatial navigation when locating leks, i.e., "ranging" (Naguib and Wiley 2001), especially during predawn periods when low light intensity prohibits the use of visual cues (Aspbury and Gibson 2004). If population sizes decline and fewer females are available on the landscape to respond to the chorus, we predict the spatial area covered by the chorus may decrease leading to lek failure because decreasing hen attendance correlates with diminished copulatory success (Höglund and Alatalo 2014). Further work on assessing how the propagation of the male boom chorus affects persistence and 
dynamics of leks may lead to an improved understanding of communication efficiency and how this natural phenomenon can be conserved.

We found evidence that the area of boom chorus propagation audible to female prairie-chickens was negatively influenced by increasing background noise, which is a cause for conservation concern because anthropogenic noise levels are increasing in many habitats (Buxton et al. 2017). This concern is especially relevant for less intact grassland systems with a high density of humanmade structures. For example, Winder and others reported adverse effects of a wind energy facility on female prairie-chicken space use (Winder et al. 2014) and lek persistence (Winder et al. 2015) in a grassland/agriculture system with almost three times $\left(1.40 \mathrm{~km} / \mathrm{km}^{2}\right)$ higher road density as our study area $(0.49 \mathrm{~km} /$ $\left.\mathrm{km}^{2}\right)$. The presence of a wind facility and concomitant background noise in our relatively intact, unfragmented landscape appears to have fewer negative consequences because females do not appear to avoid nesting (Harrison et al. 2017) or rearing broods in areas near the facility (Harrison 2015). Leks near and on wind facility property have been present after the facility's construction and still remain (B. Vodehnal, NE Game \& Parks Commission, personal communication). These contrasting results with those of other studies of Greater PrairieChickens in the context of wind energy facilities suggest further study incorporating their acoustic ecology is needed to determine factors responsible for their range contractions, especially in grasslands exposed to anthropogenic alterations to the physical and acoustic environment.

\section{CONCLUSIONS}

Our findings, to our knowledge, are the first to address the role of acoustics in lekking dynamics and potential for anthropogenic disturbance to interfere with vocalizations of Greater PrairieChickens. Our results indicate that increased noise has the potential to impact reproductive behavior by altering the efficacy of vocal communication. This is of particular concern as grouse species occupying these landscapes already face increasing habitat loss from agricultural activities, urbanization, and woody encroachment (Fuhlendorf et al. 2017, Lautenbach et al. 2017). Acoustically specialized species, such as prairie-chickens, may abandon otherwise suitable habitat in the vicinity of noisy road networks or wind energy facilities (Winder et al. 2014, Smith and Dwyer 2016). The interaction of prairie-chicken lek acoustics and behavioral processes warrants additional study. We conclude by suggesting that siting man-made infrastructure within habitats that already experience fragmentation, i.e., roads, and increased anthropogenic noise, i.e., row crop agriculture or urban peripheries (Kight et al. 2012), and not in intact, open grassland habitats may have a lesser impact on lek-mating bird populations.

Responses to this article can be read online at:

http://www.ace-eco.org/issues/responses.php/1126

\section{Acknowledgments:}

This project was funded with U.S. Fish and Wildlife Service Wildlife Restoration dollars administered by the Nebraska Game and Parks
Commission. E. J. R. and C. E. W. were supported by the School of Natural Resources, University of Nebraska-Lincoln. M. B. B. was supported by the Nebraska Environmental Trust and the Nebraska Game and Parks Commission. L. A. P. was supported by Hatch Act funds through the University of Nebraska Agricultural Research Division, Lincoln, Nebraska. For assistance, we thank J. Olney Harrison, J. Lusk, J. Mather, E. Shogren, N. Turner, and B. Vodehnal. We thank J. McGee, J. Smith, and E. Walsh for valuable input throughout the planning, data collection, and analysis phases of this project. We thank M. Gonnerman, T. Montgomery, and L. Sanders for their assistance in finding leks. We thank numerous private land owners and the Nebraska Public Power District, especially $R$. Plettner and C. Walnofer who allowed us access to their properties. We thank A. C. Keyel for assistance with SPreADGIS as well as spatial modeling advice. We especially thank A. J. Tyre, E. Stuber, J. F. Benson, and C. J. Chizinski for helpful discussions of quantitative matters. The University of NebraskaLincoln's Institutional Animal Care and Use Committee (permit \#901) approved this research.

\section{LITERATURE CITED}

Arnold, T. W. 2010. Uninformative parameters and model selection using Akaike's information criterion. Journal of Wildlife Management 74:1175-1178. http://doi.org/10.1111/j.1937-2817.2010. tb01236.x

Aspbury, A. S., and R. M. Gibson. 2004. Long-range visibility of Greater Sage Grouse leks: a GIS-based analysis. Animal Behaviour 67:1127-1132. http://doi.org/10.1016/j.anbehav.2003.06.021

Aylor, D. 1972. Noise reduction by vegetation and ground. Journal of the Acoustical Society of America 51:197-205. http://dx.doi. org/10.1121/1.1912830

Barber, J. R., C. L. Burdett, S. E. Reed, K. A. Warner, C. Formichella, K. R. Crooks, D. M. Theobald, and K. M. Fristrup. 2011. Anthropogenic noise exposure in protected natural areas: estimating the scale of ecological consequences. Landscape Ecology 26:1281-1295. http://dx.doi.org/10.1007/s10980-011-9646-7

Barber, J. R., K. R. Crooks, and K. M. Fristrup. 2010. The costs of chronic noise exposure for terrestrial organisms. Trends in Ecology \& Evolution 25:180-189. https://doi.org/10.1016/j. tree.2009.08.002

Bates, D., M. Maechler, B. Bolker, and S. Walker. 2015. Fitting linear mixed-effects models using lme4. Journal of Statistical Software 67:1-48. http://dx.doi.org/10.18637/jss.v067.i01

Bayne, E. M., L. Habib, and S. Boutin. 2008. Impacts of chronic anthropogenic noise from energy-sector activity on abundance of songbirds in the boreal forest. Conservation Biology 22:1186-1193. https://doi.org/10.1111/j.1523-1739.2008.00973.x

Bioacoustics Research Program. 2014. Raven Pro: Interactive Sound Analysis Software (Version 1.4). [Computer software]. The Cornell Lab of Ornithology, Ithaca, New York, USA. [online] URL: http://www.birds.cornell.edu/raven

Bleed, A. S., and C. Flowerday. 1998. An atlas of the Sand Hills. Conservation and Survey Division, Institute of Agriculture and Natural Resources, University of Nebraska-Lincoln, Nebraska, USA. 
Blickley, J. L., and G. L. Patricelli. 2010. Impacts of anthropogenic noise on wildlife: research priorities for the development of standards and mitigation. Journal of International Wildlife Law \& Policy 13:274-292. https://doi. org/10.1080/13880292.2010.524564

Blickley, J. L., and G. L. Patricelli. 2012. Potential acoustic masking of Greater Sage-Grouse (Centrocercus urophasianus) display components by chronic industrial noise. Ornithological Monographs 74:23-35. http://dx.doi.org/10.1525/om.2012.74.1.23

Blumstein, D. T., D. J. Mennill, P. Clemins, L. Girod, K. Yao, G. Patricelli, J. L. Deppe, A. H. Krakauer, C. Clark, K. A. Cortopassi, et al. 2011. Acoustic monitoring in terrestrial environments using microphone arrays: applications, technological considerations and prospectus. Journal of Applied Ecology 48:758-767. http://dx.doi.org/10.1111/j.1365-2664.2011.01993.x

Buxton, R. T., M. F. McKenna, D. Mennitt, K. Fristrup, K. Crooks, L. Angeloni, and G. Wittemyer. 2017. Noise pollution is pervasive in U.S. protected areas. Science 356:531-533. https://doi. org/10.1126/science.aah4783

Embleton, T. F. W. 1996. Tutorial on sound propagation outdoors. Journal of the Acoustical Society of America 100:31-48. http://dx. doi.org/10.1121/1.415879

Environmental Systems Research Institute (ESRI). 2011. ArcGIS Desktop: Release 10in ESRI, editor. ESRI, Redlands, California, USA.

Fang, C.-F., and D.-L. Ling. 2003. Investigation of the noise reduction provided by tree belts. Landscape and Urban Planning 63:187-195. https://doi.org/10.1016/S0169-2046(02)00190-1

Fargione, J., J. Kiesecker, M. J. Slaats, and S. Olimb. 2012. Wind and wildlife in the Northern Great Plains: identifying low-impact areas for wind development. PLOS ONE 7:e41468. https://doi. org/10.1371/journal.pone.0041468

Francis, C. D. 2015. Vocal traits and diet explain avian sensitivities to anthropogenic noise. Global Change Biology 21:1809-1820. https://doi.org/10.1111/gcb.12862

Francis, C. D., and J. R. Barber. 2013. A framework for understanding noise impacts on wildlife: an urgent conservation priority. Frontiers in Ecology and the Environment 11:305-313. http://dx.doi.org/10.1890/120183

Fuhlendorf, S. D., T. J. Hovick, R. D. Elmore, A. M. Tanner, D. M. Engle, and C. A. Davis. 2017. A hierarchical perspective to woody plant encroachment for conservation of prairie-chickens. Rangeland Ecology \& Management 70:9-14. https://doi. org/10.1016/j.rama.2016.08.010

Gibson, L., E. N. Wilman, and W. F. Laurance. 2017. How green is 'green' energy? Trends in Ecology \& Evolution 32:922-935. https://doi.org/10.1016/j.tree.2017.09.007

Habib, L., E. M. Bayne, and S. Boutin. 2007. Chronic industrial noise affects pairing success and age structure of ovenbirds Seiurus aurocapilla. Journal of Applied Ecology 44:176-184. http:// dx.doi.org/10.1111/j.1365-2664.2006.01234.x

Hamerstrom, F. N., Jr, and F. Hamerstrom. 1949. Daily and seasonal movements of Wisconsin prairie chickens. Auk 66:313-337. http://dx.doi.org/10.2307/4080275
Hamerstrom, F. N., Jr, and F. Hamerstrom. 1960. Comparability of some social displays of grouse. Transactions of the International Ornithological Congress 12:274-293.

Hamerstrom, F. N., Jr, O. E. Mattson, and F. Hamerstrom. 1957. A guide to prairie chicken management. Game Management Division, Wisconsin Conservation Department, Madison, Wisconsin, USA.

Harris, C. M. 1966. Absorption of sound in air versus humidity and temperature. Journal of the Acoustical Society of America 40:148-159. http://dx.doi.org/10.1121/1.1910031

Harrison, J. O. 2015. Assessment of disturbance effects of an existing wind energy facility on Greater Prairie-Chicken (Tympanuchus cupido pinnatus) breeding season ecology in the Sandhills of Nebraska. Thesis. University of Nebraska, Lincoln, Nebraska, USA.

Harrison, J. O., M. B. Brown, L. A. Powell, W. H. Schacht, and J. A. Smith. 2017. Nest site selection and nest survival of Greater Prairie-Chickens near a wind energy facility. Condor 119:659-672. http://dx.doi.org/10.1650/condor-17-51.1

Harrison, R. T., R. N. Clark, G. H. Stankey. 1980. Predicting impact of noise on recreationists. U.S. Forest Service, Equipment Development Center, San Dimas, California, USA.

Höglund, J., and R. V. Alatalo. 2014. Leks. Princeton University Press, Princeton, New Jersey, USA. http://dx.doi. org/10.1515/9781400864157

Homer, C. H., J. A. Fry, and C. A. Barnes. 2012. The national land cover database. U.S. Geological Survey Fact Sheet 3020:1-4.

Hovick, T. J., R. D. Elmore, D. K. Dahlgren, S. D. Fuhlendorf, and D. M. Engle. 2014. Evidence of negative effects of anthropogenic structures on wildlife: a review of grouse survival and behaviour. Journal of Applied Ecology 51:1680-1689. http:// dx.doi.org/10.1111/1365-2664.12331

Howard, D. M., and D. T. Murphy. 2007. Voice science, acoustics, and recording. Plural, San Diego, California, USA.

Ingård, U. 1953. A review of the influence of meteorological conditions on sound propagation. Journal of the Acoustical Society of America 25:405-411. http://dx.doi.org/10.1121/1.1907055

Keyel, A. C., S. E. Reed, M. F. McKenna, and G. Wittemyer. 2017. Modeling anthropogenic noise propagation using the Sound Mapping Tools ArcGIS toolbox. Environmental Modelling \& Software 97:56-60. https://doi.org/10.1016/j.envsoft.2017.07.008

Kight, C. R., M. K. Hinders, and J. P. Swaddle. 2012. Acoustic space is affected by anthropogenic habitat features: implications for avian vocal communication. Ornithological Monographs 74:47-62. http://dx.doi.org/10.1525/om.2012.74.1.47

Lautenbach, J. M., R. T. Plumb, S. G. Robinson, C. A. Hagen, D. A. Haukos, and J. C. Pitman. 2017. Lesser Prairie-Chicken avoidance of trees in a grassland landscape. Rangeland Ecology \& Management 70:78-86. https://doi.org/10.1016/j.rama.2016.07.008

Lohr, B., T. F. Wright, and R. J. Dooling. 2003. Detection and discrimination of natural calls in masking noise by birds: estimating the active space of a signal. Animal Behaviour 65:763-777. https://doi.org/10.1006/anbe.2003.2093 
Marten, K., and P. Marler. 1977. Sound transmission and its significance for animal vocalization. Behavioral Ecology and Sociobiology 2:271-290. https://doi.org/10.1007/bf00299740

Mason, J. T., C. J. W. McClure, and J. R. Barber. 2016. Anthropogenic noise impairs owl hunting behavior. Biological Conservation 199:29-32. http://dx.doi.org/10.1016/j.biocon.2016.04.009

McClure, C. J. W., H. E. Ware, J. D. Carlisle, and J. R. Barber. 2017. Noise from a phantom road experiment alters the age structure of a community of migrating birds. Animal Conservation 20:164-172. http://dx.doi.org/10.1111/acv.12302

McKenna, M. F., G. Shannon, and K. Fristrup. 2016. Characterizing anthropogenic noise to improve understanding and management of impacts to wildlife. Endangered Species Research 31:279-291. http://dx.doi.org/10.3354/esr00760

McNew, L. B., L. M. Hunt, A. J. Gregory, S. M. Wisely, and B. K. Sandercock. 2014. Effects of wind energy development on nesting ecology of Greater Prairie-Chickens in fragmented grasslands. Conservation Biology 28:1089-1099. http://dx.doi. org/10.1111/cobi.12258

Mennitt, D., K. Fristrup, L. Nelson, and M. McKenna. 2013. Mapping the extent of noise on a national scale using geospatial models. Journal of the Acoustical Society of America 134:4159. http://dx.doi.org/10.1121/1.4831244

Morton, E. S. 1975. Ecological sources of selection on avian sounds. American Naturalist 109:17-34. http://dx.doi.org/10.1086/282971

Naguib, M., and R. H. Wiley. 2001. Estimating the distance to a source of sound: mechanisms and adaptations for long-range communication. Animal Behaviour 62:825-837. https://doi. org/10.1006/anbe.2001.1860

Nooker, J. K., and B. K. Sandercock. 2008. Phenotypic correlates and survival consequences of male mating success in lek-mating Greater Prairie-Chickens (Tympanuchus cupido). Behavioral Ecology and Sociobiology 62:1377-1388. http://dx.doi.org/10.1007/ s00265-008-0566-8

Piercy, J. E., T. F. Embleton, and L. C. Sutherland. 1977. Review of noise propagation in the atmosphere. Journal of the Acoustical Society of America 61:1403-1418. http://dx.doi.org/10.1121/1.381455

Pruett, C. L., M. A. Patten, and D. H. Wolfe. 2009. Avoidance behavior by prairie grouse: implications for development of wind energy. Conservation Biology 23:1253-1259. http://dx.doi. org/10.1111/j.1523-1739.2009.01254.x

R Development Core Team. 2016. R: A language and environment for statistical computing. $\mathrm{R}$ Foundation for Statistical Computing, Vienna, Austria.

Raynor, E. J., C. E. Whalen, M. B. Brown, and L. A. Powell. 2017. Grassland bird community and acoustic complexity appear unaffected by proximity to a wind energy facility in the Nebraska Sandhills. Condor 119:484-496. http://dx.doi.org/10.1650/ CONDOR-16-164.1

Reed, S. E., J. L. Boggs, and J. P. Mann. 2010. SPreAD-GIS: an ArcGIS toolbox for modeling the propagation of engine noise in a wildland setting. Wilderness Society, San Francisco, California, USA.
Reed, S. E., J. L. Boggs, and J. P. Mann. 2012. A GIS tool for modeling anthropogenic noise propagation in natural ecosystems. Environmental Modelling \& Software 37:1-5. https://doi. org/10.1016/j.envsoft.2012.04.012

Rehberg-Besler, N., S. M. Doucet, and D. J. Mennill. 2017. Overlapping vocalizations produce far-reaching choruses: a test of the signal enhancement hypothesis. Behavioral Ecology 28:494-499. http://dx.doi.org/10.1093/beheco/arw176

Riebel, K. 2009. Song and female mate choice in zebra finches: a review. Advances in the Study of Behavior 40:197-238. https://doi. org/10.1016/S0065-3454(09)40006-8

Riede, T., C. M. Eliason, E. H. Miller, F. Goller, and J. A. Clarke. 2016. Coos, booms, and hoots: the evolution of closed-mouth vocal behavior in birds. Evolution 70:1734-1746. http://dx.doi. org/10.1111/evo. 12988

Riitters, K. H., and J. D. Wickham. 2003. How far to the nearest road? Frontiers in Ecology and the Environment 1:125-129. http:// dx.doi.org/10.1890/1540-9295(2003)001[0125:HFTTNR]2.0.CO;2

Robel, R. J. 1966. Booming territory size and mating success of the Greater Prairie-Chicken (Tympanuchus cupido pinnatus). Animal Behaviour 14:328-331. http://dx.doi.org/10.1016/S0003-3472 (66)80092-1

Shannon, G., M. F. McKenna, L. M. Angeloni, K. R. Crooks, K. M. Fristrup, E. Brown, K. A. Warner, M. D. Nelson, C. White, J. Briggs, S. McFarland, and G. Wittemyer. 2016. A synthesis of two decades of research documenting the effects of noise on wildlife. Biological Reviews 91:982-1005. http://dx.doi.org/10.1111/ brv. 12207

Smith, J. A., and J. F. Dwyer. 2016. Avian interactions with renewable energy infrastructure: an update. Condor 118:411-423. http://dx.doi.org/10.1650/CONDOR-15-61.1

Smith, J. A., C. E. Whalen, M. Bomberger Brown, and L. A. Powell. 2016. Indirect effects of an existing wind energy facility on lekking behavior of Greater Prairie-Chickens. Ethology 122:419-429. http://dx.doi.org/10.1111/eth.12489

Sparling, D. W. 1981a. Communication in prairie grouse: I. Information content and intraspecific functions of principal vocalizations. Behavioral and Neural Biology 32:463-486. https:// doi.org/10.1016/S0163-1047(81)90904-3

Sparling, D. W. 1981b. Communication in prairie grouse: II. Ethological isolating mechanisms. Behavorial and Neural Biology 32:487-503. https://doi.org/10.1016/S0163-1047(81)90917-1

Sparling, D. W. 1983. Quantitative analysis of prairie grouse vocalizations. Condor 85:30-42. http://dx.doi.org/10.2307/1367883

Sutherland, L. C., J. E. Piercy, H. E. Bass, and L. B. Evans. 1974. Method for calculation of the absorption of sound by the atmosphere. Journal of the Acoustical Society of America. 56(S1). http://dx.doi.org/10.1121/1.1914056

Walsh, E. J., C. Whalen, L. Powell, M. B. Brown, and J. McGee 2015. Hearing sensitivity in the Greater Prairie-Chicken (Tympanuchus cupido). Journal of the Acoustical Society of America 137:2219-2219. http://dx.doi.org/10.1121/1.4920084 
Ware, H. E., C. J. W. McClure, J. D. Carlisle, and J. R. Barber. 2015. A phantom road experiment reveals traffic noise is an invisible source of habitat degradation. Proceedings of the National Academy of Sciences 112:12105-12109. http://dx.doi. org/10.1073/pnas.1504710112

Whalen, C. E. 2015. Effects of wind turbine noise on male Greater Prairie-Chicken vocalizations and chorus. Thesis. University of Nebraska-Lincoln, Lincoln, Nebraska, USA.

Whalen, C. E., M. B. Brown, J. McGee, L. A. Powell, and E. J. Walsh. 2017. Acoustic characteristics of lekking male Greater Prairie-Chicken (Tympanuchus cupido pinnatus) vocalizations (Supplement). Great Plains Research 27:93-108. https://doi. org/10.1353/gpr.2017.0018

Whalen, C. E., M. B. Brown, J. McGee, L. A. Powell, and E. J. Walsh. 2018. Male Greater Prairie-Chickens adjust their vocalizations in the presence of wind turbine noise. Condor, in press.

Winder, V. L., A. J. Gregory, L. B. McNew, and B. K. Sandercock. 2015. Responses of male Greater Prairie-Chickens to wind energy development. Condor 117:284-296. http://dx.doi.org/10.1650/ CONDOR-14-98.1

Winder, V. L., L. B. McNew, A. J. Gregory, L. M. Hunt, S. M. Wisely, and B. K. Sandercock. 2014. Space use by female Greater Prairie-Chickens in response to wind energy development. Ecosphere 5:1-17. http://dx.doi.org/10.1890/ES13-00206.1

Zwart, M. C., J. C. Dunn, P. J. K. McGowan, and M. J. Whittingham. 2016. Wind farm noise suppresses territorial defense behavior in a songbird. Behavioral Ecology 27:101-108. http://dx.doi.org/10.1093/beheco/arv128 


\section{Appendix 1. Supplementary information on methodology and chorus projections}

Location matters: evaluating Greater Prairie-Chicken (Tympanuchus cupido) boom chorus propagation

\section{Supplemental Methods}

\section{Study area}

The landscape is dominated by grass species including little bluestem (Schizachyrium scoparium), switchgrass (Panicum virgatum), and prairie sandreed (Calamovilfa longifolia). Land use is primarily low-density cattle ranching $(80 \%)$, hay production $(10 \%)$, and cultivated crop production including corn (Zea mays), soy (Glycince max), and alfalfa (Medicago sativa) that are supported by irrigation (5\%; Miller 1998). Average temperatures range from the mid $20^{\circ}$ Cs in July to approximately $-5^{\circ} \mathrm{C}$ in January, and precipitation averages $53 \mathrm{~cm}$ annually, with $50 \%$ falling between May and July. On average, wind speeds exceed $8.5 \mathrm{~m} / \mathrm{s}$ at $80 \mathrm{~m}$ above ground (average height of a wind turbine hub). Each of the 36 turbines at the wind facility occupies a footprint of approximately $0.002 \mathrm{~km}^{2}(0.2 \mathrm{ha})$, stands $70 \mathrm{~m}$ tall at the hub, and has a rotor radius of $41 \mathrm{~m}$ (rotor swept area $=5,281 \mathrm{~m}^{2}$ ) (NPPD 2017). The turbines operate intermittently, at an estimated $40 \%$ of the full capacity (1.65 MW/turbine; NPPD 2017).

\section{Weather data}

Because the weather station collected data higher above the ground than the Kestrel Weather Meter, we conducted a regression analysis to estimate the 'kestrel' data from the 'weather station' data. We conducted a separate regression analysis (PROC GLIMMIX; SAS Institute Inc., Cary, NC) for each weather variable (wind speed, temperature, and humidity) with data from days for which we had both kestrel and weather station data. The response variable in each regression analysis was the 'kestrel data.' The explanatory variables in each regression analysis were the 'weather station data' and the distance between the weather station and the lek where the 'kestrel data' was collected. We used the resulting linear models to estimate the weather data at the leks for missing at-lek measurements.

\section{Calibration process}

During the calibration, we recorded tones of known frequency and sound pressure level for one minute for each preamplifier gain and both microphones attached to each audio recorder. Sound pressure levels were confirmed with a Type-1 Sound Level Meter (Larson Davis Model 831, PCB Piezotronics, Inc., Depew, NY). The maximum power of each known sound recorded on each channel of the audio recorders was measured in Raven (Hann window type, 100ms window size, $14.4 \mathrm{~Hz} 3 \mathrm{~dB}$ filter bandwidth; Charif et al. 2010). The difference between the known sound pressure level ( $\mathrm{dB}$ SPL re $20 \mu \mathrm{Pa}$ ) and the maximum power $(\mathrm{dB})$ was used to calculate calibration correction factors for both microphones/channels of each audio recorder. Audio 
recorders were calibrated before and after each field season and averaged calibration correction factors from the 'before' and 'after' season calibration sessions were assigned to each microphone for the entire field season (Whalen 2015). When correcting the boom chorus sound pressure levels, we added the calibration correction factors to the uncalibrated levels.

\section{SPreAD-GIS}

SPreAD-GIS uses a modified National Landcover Database (Homer et al. 2012) raster file collapsed into seven categories: water, coniferous forest, herbaceous grassland, deciduous forest, shrubland, and developed land. Leks were located in herbaceous grassland and background noise levels from recording were used to represent sound of herbaceous grassland landcover (Table A1.2). Roads are included in the urban/developed land cover. Topography is calculated from a digital elevation model of the study area. Sound Pressure Levels ( $\mathrm{dB}$ unweighted) values for land covered by urban/developed (i.e., roads), barren land, forest types, and wetland sound sources were derived from Harrison et al. (1980) and (American National Standards Institute 2004) (Table A1.2). These values were used to populate background sound tables for use in calculation of audible area (i.e., excess attenuation) raster projections (resolution $=30 \mathrm{~m}$ ) (Table A1.2; Reed et al. 2010). Excess attenuation values (dB) are what remains from the sound propagation raster after taking into account environmental influences including spherical spreading loss, atmospheric absorption, foliage/ground loss and terrain and wind effects (Fig. A1.2 in gray). Background noise levels from leks recordings were used to represent the sound of herbaceous grassland landcover; all leks were located in herbaceous grassland. Roads are included in the urban/developed land cover.

We validated the model by 1 ) determining the number of pixels with excess attenuation values $>$ $0 \mathrm{~dB}$ that overlapped pixels containing the recording points with signal to noise ratio $>0 \mathrm{~dB}$ and 2) comparing $\mathrm{dB}$ values in excess attenuation rasters to the difference of the chorus and background noise (i.e., signal to noise ratio) at $\sim 0.300 \mathrm{kHz}$ recorded along locations crossing the lek (details in Whalen 2015). A total of $57 \%$ of the transect points sampled for model validation overlapped with the raster cells that were predicted to have excess attenuation values above zero $\mathrm{dB}$. Therefore, more than half of the transect points with signal to noise ratios above zero overlapped raster cell values with predicted excess attenuation above zero, which allowed us to assess how well signal to noise ratio $(\mathrm{dB})$ explained the spatial projections of $\mathrm{dB}$ at $30 \mathrm{~m}$ resolution. Signal to noise ratio explained $25 \%$ of the variability in the predicted excess attenuation $\mathrm{dB}$ values at locations along the $\mathrm{N}, \mathrm{S}, \mathrm{E}$, and $\mathrm{W}$ recording locations extending out from the lek (simple linear regression: $\mathrm{R}^{2}=0.25, \mathrm{~F}_{1,2482}=861.9, \mathrm{P}<0.001$ ).

\section{Literature cited}

American National Standards Institute. 2004. Method for calculation of the absorption of sound by the atmosphere. Acoustic Society of America. New York, NY.

Charif, R.A., A.M. Waack, and L.M. Strickman. 2010. Raven Pro 1.4 User's Manual. Cornell Lab of Ornithology, Ithaca, NY.

Miller, S. 1998. Land development and use. Pages 219-238 in A. Bleed, and C. Flowerday, editors. An atlas of the Sand Hills. Conservation and Survey Division, University of Nebraska, Lincoln, Nebraska, USA. 
Reed, S.E., J.L. Boggs, and J.P. Mann. 2010. SPreAD-GIS: an ArcGIS toolbox for modeling the propagation of engine noise in a wildland setting. Version 2.0. The Wilderness Society, San Francisco, CA. URL: https://www.scribd.com/document/259951647/SPreAD-GIS-User-sGuide-v2-0

Whalen, C. E. 2015. Effects of wind turbine noise on male Greater Prairie-Chicken vocalizations and chorus. M.S. thesis, University of Nebraska-Lincoln, Lincoln, NE, USA. 
Table A1.1. Example source sound table for SPreAD-GIS from lek recordings on 4/06/2013 at lek A1 near Ainsworth, Nebraska. dB represents average boom chorus sound level in a five minute recording. Weather conditions were recorded at leks.

\begin{tabular}{llllllll}
\hline $\begin{array}{l}\text { Frequency } \\
(\mathrm{kHz})\end{array}$ & $\mathrm{dB}$ & $\begin{array}{l}\text { Measurement } \\
(\mathrm{SPL})\end{array}$ & Distance $(\mathrm{m})$ & Wind speed $(\mathrm{m} / \mathrm{s})$ & Wind direction $\left({ }^{\circ}\right)$ & Temp $\left({ }^{\circ} \mathrm{C}\right)$ & $\begin{array}{l}\text { Relative } \\
\text { Humidity }\end{array}$ \\
\hline 0.315 & 53.24 & 50 & 9 & 298 & 8 & 78 & Filename \\
0.315 & 49.245 & 50 & 10 & 286 & 8 & 80 & A1_2013-04-06_650 \\
0.315 & 50.925 & 50 & 8 & 278 & 9 & 80 & A1_2013-04-06_710 \\
0.315 & 41.28 & 50 & 13 & 275 & 9 & 76 & A1_2013-04-06_730 \\
\hline
\end{tabular}


Table A1.2. Example background sound table for SPreAD-GIS from lek recordings on 4/06/2013 at lek A1 near Ainsworth, Nebraska. Land cover (dB) extrapolated from ANSI 2004 and Harrison et al. 1980. Cover derived from National Landcover Database: conifer (CON), hardwood (HWD), shrub (SHB), barren (BAR), urban (URB) and wetlands (WAT).

*Herbaceous (HEB) grassland $\mathrm{dB}$ are average background sound level in a five-minute recording within same range of wind speed.

\begin{tabular}{rlrrr}
\hline Frequency $(\mathrm{kHz})$ & Cover & dB (SPL) & WindMin $(\mathrm{m} / \mathrm{s})$ & WindMax $(\mathrm{m} / \mathrm{s})$ \\
\hline 0.315 & CON & 20 & 0 & 1 \\
0.315 & CON & 28 & 1 & 5 \\
0.315 & CON & 33 & 5 & 15 \\
0.315 & CON & 41 & 15 & 300 \\
0.315 & HWD & 18 & 0 & 1 \\
0.315 & HWD & 22 & 1 & 5 \\
0.315 & HWD & 28 & 5 & 15 \\
0.315 & HWD & 30 & 15 & 300 \\
0.315 & SHB & 18 & 0 & 1 \\
0.315 & SHB & 26 & 1 & 5 \\
0.315 & SHB & 27 & 5 & 15 \\
0.315 & SHB & 29 & 15 & 300 \\
0.315 & BAR & 13 & 0 & 1 \\
0.315 & BAR & 21 & 1 & 5 \\
0.315 & BAR & 22 & 5 & 15 \\
0.315 & BAR & 23 & 15 & 300 \\
0.315 & URB & 31 & 0 & 1 \\
0.315 & URB & 32 & 1 & 5 \\
0.315 & URB & 33 & 5 & 15 \\
0.315 & URB & 34 & 15 & 300 \\
0.315 & WAT & 31 & 0 & 1 \\
0.315 & WAT & 36 & 1 & 5 \\
0.315 & WAT & 44 & 5 & 15 \\
0.315 & WAT & 45 & 15 & 15 \\
0.315 & HEB* & 13 & 0 & 15 \\
0.315 & HEB* & 20 & 1 & 300 \\
0.315 & HEB* & 25 & 15 & \\
0.315 & HEB* & 32 & & 500 \\
& & & 0 & \\
& & & \\
\hline
\end{tabular}




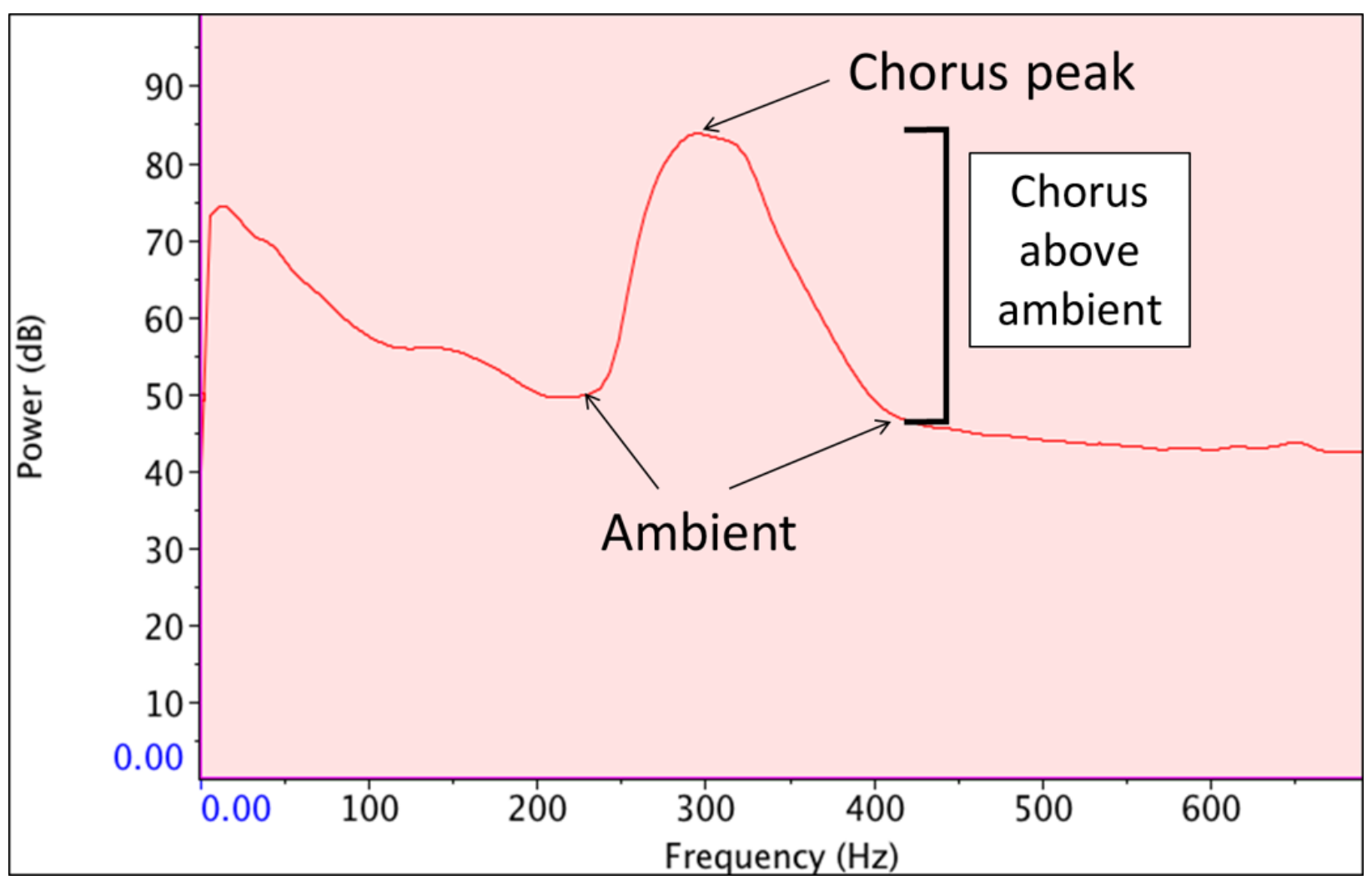

Figure A1.1. Depiction of the method used to extract boom chorus peak and ambient background noise sound pressure levels at $\sim 0.300 \mathrm{kHz}$ in the 383 usable recordings collected near Ainsworth, Brown County, Nebraska, USA in 2013 and 2014. The chorus peak and background sound levels at $50 \mathrm{~m}$ from the lek were used as the level of boom chorus (the source) originating from the lek and grassland cover type background noise, respectively, in each of the 383 chorus propagation maps generated with SPreAD-GIS. 